Clinical Trial. Clinical Medicine Insights: Arthritis and Musculoskeletal Disorders. 2017:10:1179544117733452.

[3] Raeissadat SA, Rayegani SM, Hassanabadi H, Fathi M, Ghorbani E, Babaee M, et al. Knee osteoarthritis injection choices: platelet-rich plasma (PRP) versus hyaluronic acid (a one-year randomized clinical trial). Clinical Medicine Insights: Arthritis and Musculoskeletal Disorders. 2015;8: CMAMD. S17894.

[4] Raeissadat SA, Rayegani SM, Moridnia M, Dehgolan SR. AB1246-HPR Intra articular ozone or hyaluronic acid injection: which one is superior in patients with knee osteoarthritis? a 6-month randomized clinical trial. BMJ Publishing Group Ltd; 2017.

Disclosure of Interest: None declared DOI: 10.1136/annrheumdis-2018-eular.7211

\section{AB0976 EFFICACY OF INTRA-ARTICULAR INJECTION OF PRP- DRIVED GROWTH FACTOR (PRP WITHOUT PLATELET AND WBC) VERSUS HYALURONIC ACID ON PAIN AND FUNCTION OF PATIENTS WITH KNEE OSTEOARTHRITIS: A SINGLE-BLINDED RANDOMISED CLINICAL TRIAL}

S.A. Raeissadat, A. gharooee ahangar, S.M. Rayegani. physical medicine and rehabilitation, shahid beheshti university of medical science, tehran, Iran, Islamic Republic of Ireland

Background: Knee osteoarthritis is the most common joint disease.

Objectives: We aimed to compare the efficacy and safety of intra-articular injection of PRP-drived growth factor versus hyaluronic acid (HA) on pain and function of patients with knee osteoarthritis.

Methods: In this single-blinded randomised clinical trial, patients with symptomatic osteoarthritis of knee were assigned to receive 2 intra-articular injections of PRP-drived growth factor in 3 weeks or 3 weekly injections of HA. Our primary outcome was the mean change from baseline until 2 and 6 months post intervention in scores of visual analogue scale, Western Ontario and McMaster Universities Osteoarthritis Index (WOMAC), and Lequesne index.

Results: A total of 69 patients entered final analysis. The mean age of patients was $58.2 \pm 7.41$ years and $81.2 \%$ were women. Total WOMAC index decreased from $42.9 \pm 13.51$ to $26.8 \pm 13.45$ and $24.4 \pm 16.54$ at 2 and 6 months in the PRGF group (within subjects $p=0.001$ ), and from $38.8 \pm 12.62$ to $27.8 \pm 11.01$ and $27.4 \pm 11.38$ at 2 and 6 months in the HA group (within subjects $p=0.001$ ), respectively (between subjects $p=0.631$ ). There was no significant difference between PRP-drived growth factor and HA groups in patients' satisfaction and minor complications of injection, whereas patients in HA group reported significantly lower injection-induced pain.

Abstract AB0976 - Table 1

\begin{tabular}{|c|c|c|c|c|c|c|}
\hline \multicolumn{6}{|c|}{ WOMAC scores } & \multirow[t]{2}{*}{ VAS } \\
\hline & & Pain & Function & Stiffness & Total & \\
\hline \multirow[t]{5}{*}{ PRGF } & Baseline & $9.2 \pm 2.97$ & $\begin{array}{c}30.6 \\
\pm 10.09\end{array}$ & $3.0 \pm 2.01$ & $\begin{array}{c}42.9 \\
\pm 13.51\end{array}$ & $7.8 \pm 1.78$ \\
\hline & At 2 month & $5.8 \pm 2.96$ & $19.5 \pm 9.79$ & $1.6 \pm 1.66$ & $\begin{array}{c}26.8 \\
\pm 13.45\end{array}$ & $4.9 \pm 2.21$ \\
\hline & At 6 month & $5.3 \pm 3.60$ & $\begin{array}{c}17.6 \\
\pm 11.70\end{array}$ & $1.5 \pm 1.84$ & $\begin{array}{c}24.4 \\
\pm 16.54\end{array}$ & $4.6 \pm 2.78$ \\
\hline & $\begin{array}{l}P \text { value within } \\
\text { groups }\end{array}$ & 0.0001 & 0.0001 & 0.0001 & 0.0001 & 0.0001 \\
\hline & Hyalgan & Baseline & $8.7 \pm 3.01$ & $\begin{array}{r}27.8 \\
\pm 9.62 \\
\end{array}$ & $2.3 \pm 1.64$ & $\begin{array}{c}38.8 \\
\pm 12.62 \\
\end{array}$ \\
\hline
\end{tabular}

$7.4 \pm 1.48$

At 2 month

$5.9 \pm 2.65$

$20.6 \pm 8.04$

$1.2 \pm 1.39$

$27.8 \pm 11.01$

$4.8 \pm 1.80$

At 6 month

$5.9 \pm 2.79$

$20.1 \pm 7.77$

$1.3 \pm 1.48$

$27.4 \pm 11.38$

$4.8 \pm 2.39$

$P$ value within groups

0.0001
0.0001

0.0001

0.0001

0.0001

$P$ value Between Groups

0.847

0.894

0.189

0.985

0.648
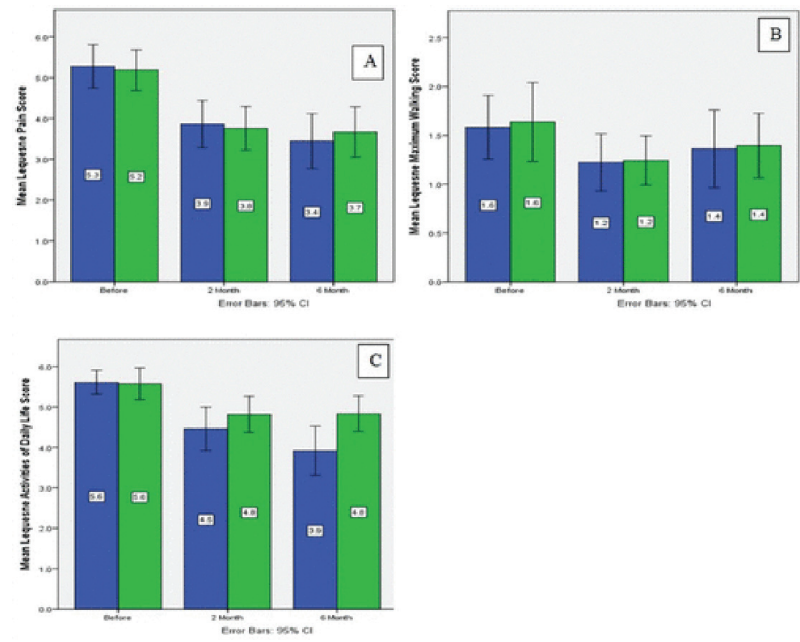

Abstract AB0976 - Figure 1

Conclusions: In 6 months follow up, PRP-drived growth factor and HA, both are effective options to decrease pain and improvement of function in patients with mild to moderate knee osteoarthritis.

\section{REFERENCES}

[1] Raeissadat, SA, Babaee, M, Rayegani, SM. An overview of platelet prod ucts (PRP, PRGF, PRF, etc.) in the Iranian studies [published online ahead of print July 28, 2017]. Futur Sci OA. doi:10.4155/fsoa-2017-0045.

[2] Raeissadat, SA, Rayegani, SM, Babaee, M, Ghorbani, E. The effect of platelet-rich plasma on pain, function, and quality of life of patients with knee osteoarthritis. Pain Res Treat. 2013;2013:165967. Google Scholar

[3] Raeissadat, SA, Rayegani, SM, Hassanabadi, H. Knee osteoarthritis injection choices: platelet-rich plasma (PRP) versus hyaluronic acid (a one-year randomized clinical trial). Clin Med Insights Arthritis Musculoskelet Disord. 2015;8:1-8.

[4] Raeissadat SA, Rayegani SM, Moridnia M, Dehgolan SR. Intra articula ozone or hyaluronic acid injection: which one is superior in patients with knee osteoarthritis? a 6-month randomized clinical trial.Annals of the Rheumatic Diseases 2017;76(Suppl 2):1547-1548.

Disclosure of Interest: None declared

DOI: 10.1136/annrheumdis-2018-eular.3701

\section{AB0977 CORRELATION OF THE LEVEL OF C-REACTIVE PROTEIN AND BONE MINERAL DENSITY IN PATIENTS WITH GONARTHRITIS}

T. Tarasenko. Polyclinic, Regional Clinical Hospital named after I.I. Mechnikov, Dnipro, Ukraine

Background: The results of recent studies also indicate a link between loss of bone mineral density (BMD) and progressive loss of articular cartilage in patients with knee joint osteoarthritis $(\mathrm{OA})$. The presence of correlation of changes in bone tissue and degradation of cartilage in $\mathrm{OA}$ is due to the possible presence of common pathogenesis chains, including activation of proinflammatory mediators.

Objectives: Determine the relationship between the level of $\mathrm{C}$-reactive protein (CRP) and the level of BMD in patients with gonarthritis.

Methods: We conducted a cross sectional study including confirmed radiographic knee osteoarthritis according to Kellgren-Lawrence scale, with norma and reduced BMD according to the classification of Report of a WHO Study Group. The structural and functional status of bone tissue in patients was 